\title{
Fish otoliths from the middle Miocene Pebas Formation of the Peruvian Amazon
}

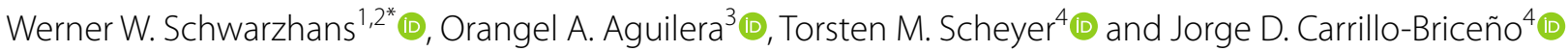

\begin{abstract}
A small assemblage of 22 otoliths was identified from the historical collection of Bluntschli and Peyer gathered in 1912 on the Itaya riverbank at lquitos, Peru (Amazonia), from the Pebas Formation. The Pebas Mega-Wetland System in western Amazonia during the Miocene represented a unique, albeit short-lived, biotope characterized by a pronounced endemic evolution with gigantism in some vertebrate groups (e.g., turtles, crocodylians). Thus far, fishes have mainly been recorded based on isolated skeletal remains and teeth. Here, we describe the first well-preserved otolith assemblage from the Pebas Formation. This otolith assemblage adds a new facet to the fauna by complementing the skeletal bony fish data, primarily with species of the Sciaenidae and, to a lesser extent, Ariidae and Cichlidae. The sciaenids and ariids indicate that migration must have occurred between the marginal marine environments to the north and the Pebas Wetland System. The otoliths also indicate the likelihood of endemic developments of adapted marine immigrants to the Pebas Wetland System, some of which have become extinct (Pogonias, Umbrina), while others now represent typical South American freshwater fish groups (Plagioscion). Six new species are described based on otoliths, one in the Cichlidae-Cichlasoma bluntschlii n. sp., one in the Ariidae-Cantarius ohei n. sp., and four in the Sciaenidae—Pebasciaena amazoniensis n. gen. et n. sp., Plagioscion peyeri n. sp., Pogonias tetragonus n. sp. and Umbrina pachaula n. sp.
\end{abstract}

Keywords: South America, Western Amazonia, Neogene, Freshwater, Brackish, Ariidae, Sciaenidae, Cichlidae

\section{Introduction}

The Pebas Mega-Wetland System during the Miocene of western Amazonia represented a unique and complex freshwater to paralic palaeoenvironment with deltas, lakes, embayments, swamps, and rivers of more than 1 million $\mathrm{km}^{2}$ in size (e.g., Gross et al., 2011; Hoorn et al., 2010; Salas-Gismondi et al., 2015, and references therein). It was the location of a highly diverse endemic evolution of the biota, a large part of which is now extinct (e.g., Monsch, 1998; Salas-Gismondi, 2006, and references therein). This study aims at providing descriptions of the fossil otoliths collected near the city of Iquitos

\footnotetext{
Editorialhandling: Daniel Marty.

*Correspondence: wwschwarz@aol.com

${ }^{1}$ Zoological Museum, Natural History Museum of Denmark,

Universitetsparken 15, 2100 København, Denmark

Full list of author information is available at the end of the article
}

(Department of Loreto, Fig. 1) during the Bluntschli and Peyer expedition of 1912 (see Carrillo-Briceño et al., 2021). This collection represents only the second record of otoliths from the Pebas Wetland System after Monsch (1998), the latter being reviewed as far as possible from his documentation. All the studied specimens were collected from sediments on the banks of the Itaya River, outcrops that are recognized as belonging to the Miocene Pebas Formation (Fm.) (de Greve, 1938; Wesselingh et al., 2002, fig. 17; Carrillo-Briceño et al., 2021).

\section{Materials and methods}

Referred specimens: The sample is represented by 22 otoliths, which are housed in the Palaeontological Institute of the University of Zurich (PIMUZ A/I). The images of the specimens were captured with a Canon EOS $1000 \mathrm{D}$ digital camera mounted on a Wild M400 photomacroscope and remotely controlled from a computer. 


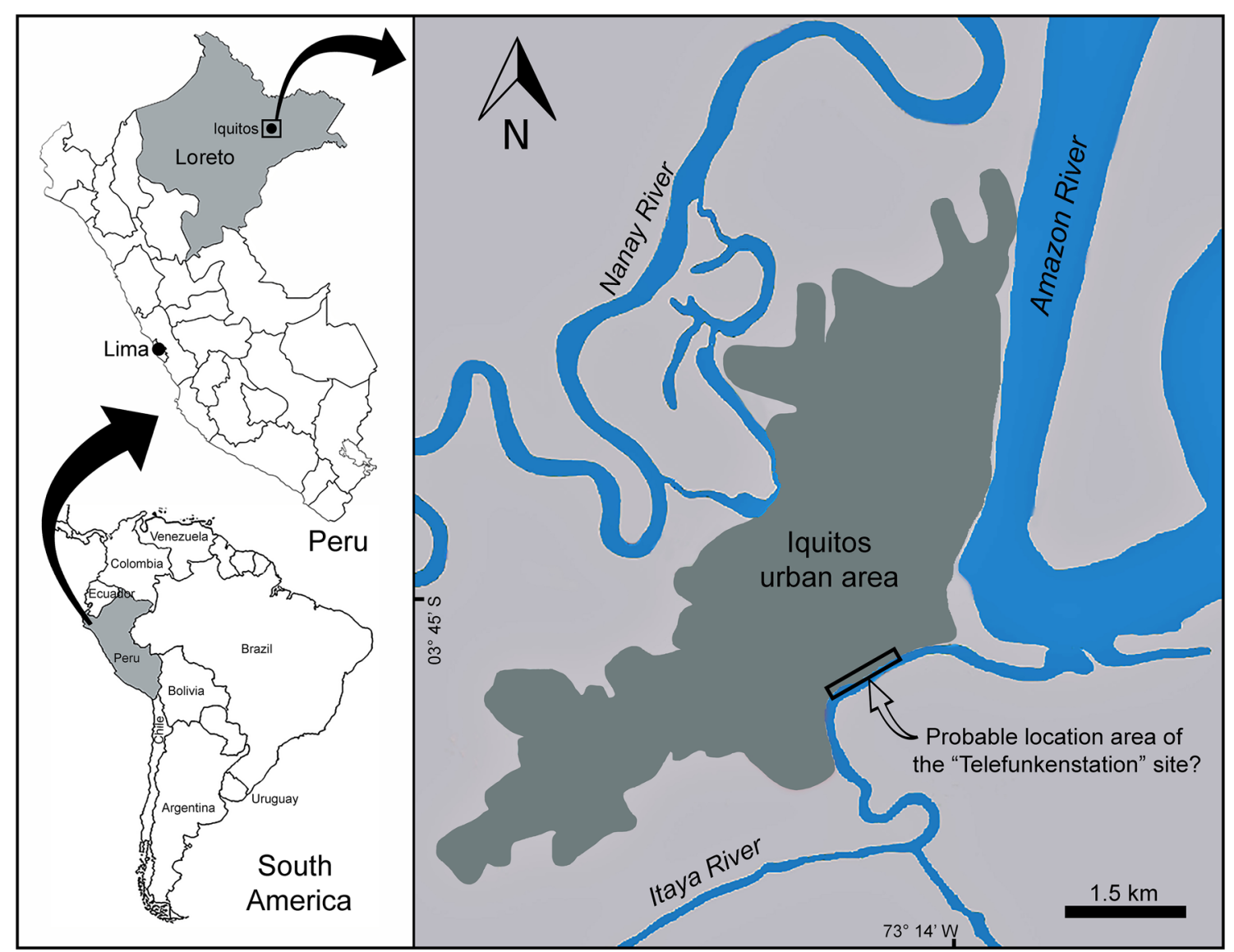

Fig. 1 Geographic location of Iquitos city in Loreto, Peru. The black rectangle on the left bank of the Itaya River suggests the probable location area of the "Telefunkenstation" (telegraph station) site of the 1912 Bluntschli and Peyer expedition (de Greve, 1938). This is tentatively based on the location of the "Torre inalambrica" on the map "Plano de la situación de Iquitos" (1:20,000) elaborated by Andrés Torres in 1918. The "Iquitos-Itaya" locality $\mathrm{N}^{\circ} 25$ in Wesselingh et al., (2002, fig. 17) is located in the same area. The map of the lquitos area is modified after Joseph et al. (2014)

Individual photographs of each view of each object were stacked to produce a continuously focused picture using HeliconSoft's HeliconFocus software. The stacked photographs were digitally adjusted for contrast and exposure and retouched when necessary and when doing so was possible without altering morphological features. Taxonomic identification involved comparisons with fossil and extant specimens as described in Schwarzhans (1993) and Aguilera et al. (2016).

Localities: The fossil invertebrates and vertebrates from Iquitos collected during the Bluntschli and Peyer expedition come from seven different layers (see de Greve, 1938, table 1; Carrillo-Briceño et al., 2021, table 1). The studied specimens come from layers VI and I [see Table 1 and Carrillo-Briceño et al. (2021)]. Both layers VI and I are associated with the same outcrop section at the Telefunkenstation (telegraph station) site (de Greve, 1938).
The lack of historical information on the stratigraphic context of the fossiliferous layers and outcrops prevented Carrillo-Briceño et al. (2021) from obtaining more detailed information on the stratigraphic position of each of the layers. The fossiliferous localities visited during the 1912 expedition were likely situated within the urban area or the vicinity of the city of Iquitos and, due to water erosion and more than a century's worth of urban growth, establishing their exact locations may not be possible. Nevertheless, Fig. 1 presents a tentative probable location of the "Telefunkenstation" site. Abundant fish remains, and some crocodylians, have been reported in this layer I (Table 1). In contrast, the only vertebrates known to date for layer VI correspond to 10 of the otoliths described here (Table 1). For both localities VI and I, de Greve (1938) reported abundant molluscan remains (see Carrillo-Briceño et al., 2021, additional file 4). 
Table 1 Otolith- and skeleton-based taxa in the Pebas Fm. from the Bluntschli and Peyer collection

\begin{tabular}{|c|c|c|c|c|c|}
\hline \multicolumn{4}{|l|}{ Taxonomy } & \multicolumn{2}{|c|}{ Layer } \\
\hline Higher ranking & Family & Genus & Species & I & VI \\
\hline \multicolumn{6}{|l|}{ Chondrichthyes } \\
\hline \multirow[t]{3}{*}{ Myliobatiformes } & Potamotrygonidae & Potamotrygon & aff. $+P$. rajachloeae & $\mathrm{T}$ & \\
\hline & & Potamotrygon & †P. canaanorum & $\mathrm{T}$ & \\
\hline & & Indet & Indet & $\mathrm{T}$ & \\
\hline \multicolumn{6}{|l|}{ Osteichthyes } \\
\hline \multirow[t]{2}{*}{ Siluriformes } & Ariidae & Cantarius & nolfi & $\mathrm{O}$ & \\
\hline & & Cantarius & ohei n. sp. & & $\mathrm{O}$ \\
\hline \multirow[t]{2}{*}{ Cichliformes } & Cichlidae & Cichlasoma & blunschlii n. sp. & $\mathrm{O}$ & \\
\hline & & Indet & Indet & B & \\
\hline \multirow[t]{7}{*}{ Perciformes } & Percoidei indet & Indet & Indet & $\mathrm{O}$ & \\
\hline & Sciaenidae & Pebasciaena n. gen. & amazonensis n. sp. & & O \\
\hline & & Plagioscion & peyeri n. sp. & $\mathrm{O}$ & $\mathrm{O}$ \\
\hline & & Pogonias & tetragonus n. sp. & $\mathrm{O}$ & $\mathrm{O}$ \\
\hline & & Sciaenops? & sp. & $\mathrm{O}$ & \\
\hline & & Umbrina & pachaula n. sp. & $\mathrm{O}$ & \\
\hline & ?Sciaenidae (pharyngeal teeth) & Indet & Indet & $\mathrm{T}$ & $\mathrm{T}$ \\
\hline \multirow[t]{10}{*}{ Characiformes } & ?Bryconidae/Characidae & Indet & Indet & $\mathrm{T}$ & \\
\hline & Cynodontidae & Indet & Indet & $\mathrm{T}$ & \\
\hline & Hemiodontidae & Hemiodus & sp. & $\mathrm{T}$ & \\
\hline & Serrasalmidae & cf. Mylossoma & sp. & $\mathrm{T}$ & \\
\hline & & "pacu" or "Myleus" clades & Indet & $B, T$ & \\
\hline & & cf. Serrasalmus & sp. & T & \\
\hline & Callichthyidae & Indet & Indet & B & \\
\hline & Doradidae & Indet & Indet & B & \\
\hline & Loricariidae & Indet & Indet & $B, T$ & \\
\hline & Pimelodidae & Indet & Indet & B & \\
\hline Osteoglossiformes & ?Osteoglossoidei & Indet & Indet & S & \\
\hline Incertae sedis & ?†Acregoliathidae & ?†Acregoliath & sp. & S & \\
\hline Indet & Indet & Indet & Indet & $B, T$ & \\
\hline \multicolumn{6}{|l|}{ Reptilia } \\
\hline Crocodylia-Alligatoridae & Indet & Indet & Indet & $\mathrm{T}$ & \\
\hline
\end{tabular}

O otolith, B skeletal remains, S scales, $T$ teeth. Fossil records of "B," "S," and "T" were reported previously in Carrillo-Briceño et al. (2021)

Table 2 Extant and fossil environmental distribution of otolith-based genera identified from the Pebas Fm. Pebasciaena not shown, since it is known from the Pebas Fm. only

\begin{tabular}{|l|l|l|l|}
\hline Genus & freshwater & brackish water & marine \\
\hline Cantarius & & & \\
\hline Cichlasoma & & & \\
\hline Plagioscion & & & \\
\hline Pogonias & & & \\
\hline Aplodinotus* & & & \\
\hline Sciaenops & & & \\
\hline Umbrina & & & \\
\hline
\end{tabular}

Aplodinotus (with *) is shown as the putative closest relative of Pogonias. The black bar indicates extant occurrence of genus, while the grey bar indicates fossil occurrence of genus other than in the Pebas Fm 


\section{Geological setting}

The Pebas Fm., which is equivalent to the Brazilian Solimões Fm. (see Cozzuol, 2006), is a lithostratigraphic unit that crops out in western and central Amazonia and is well exposed in the northeast Peru. Most of the Pebas Fm. is characterized by a succession of grey or blue clays, occasionally interrupted by unconsolidated sands, mollusk shell beds, and fossiliferous lignite layers with an age ranging from the earliest Miocene to the early late Miocene age (Roddaz et al., 2005; Salas-Gismondi et al., 2015). Based on the molluscan zones (MZs) proposed by Wesselingh et al. (2006), the city of Iquitos and its surroundings, respectively, correspond to the MZ6 (15$14 \mathrm{Ma}$ ) and MZ7 (14-12 Ma) zones.

Environments recorded in the Pebas Fm. include fluvio-lacustrine, shallow lacustrine, lacustrine, and mangrove-like areas; there is also some evidence of marine incursions (Carrillo-Briceño et al., 2021). The biostratigraphy of these depositional sequences has primarily been based on the abundant mollusk assemblages, as well as on pollen and ostracods (Alvim et al., 2021; Boonstra et al., 2015; Hoorn \& Wesselingh, 2010; Jaramillo et al., 2017; Linhares et al., 2017; Roddaz et al., 2005; SalasGismondi et al., 2015; Wesselingh et al., 2002, 2006, 2010). Prior to the establishment of the drainage system of the modern Amazon River, the Pebas Wetland System extended over more than 1 million $\mathrm{km}^{2}$, and the basin drained towards the Caribbean (Hoorn et al., 2010; SalasGismondi et al., 2015; Wesselingh et al., 2002). Abundant aquatic and terrestrial vertebrate taxa, including fishes, snakes, lizards, turtles, and aquatic and terrestrial mammals, have also been reported from several Pebasian intervals (e.g., Antoine et al., 2016; Chabain et al., 2017; Hoorn \& Wesselingh, 2010; Monsch, 1998; SalasGismondi, 2015; Tejada-Lara et al., 2015, and references therein). In addition, the region has also been highlighted as being a hotspot for the diversification of crocodylians (Salas-Gismondi et al., 2015).

\section{Systematic paleontology}

The systematic description follows the system of Nelson et al. (2016).

\section{Division Teleostei \\ Order Siluriformes \\ Family Ariidae}

The morphometric measurements in the following descriptions of ariid otoliths follow that established in Aguilera et al. (2013).

Genus Cantarius Aguilera et al., (2013)

\section{Cantarius nolfi Aguilera et al., (2013)}

Figure 2G-K
1998 Ariidae indet.-Monsch: pl. 4, Fig. 19.

1998 Arius sp.-Monsch: pl. 4, Fig. 20.

Material. One specimen, PIMUZ A/I 4998, Pebas Fm., middle Miocene, Iquitos (layer I), Peru.

Diagnosis. Otolith thick, ovoid with biconvex outline contour (vs. clam to rounded shape in other Ariidae species).

Description. The lapillus is regularly oval and thick; its anterior margin is slightly concave. Caudal margin slightly rounded. Antero-mesial projection small and rounded. Umbo located on anterior part of dorsal surface, which is irregular and very convex. Ventral surface convex. Pseudocauda of mesial shallow depression forms an arch and expands posteriorly. Mesial inward curvature forming a well-developed wedge oriented posteriorly. Ratio lapillus length to width: 1.3. Ratio lapillus length to thickness: 2.3.

Discussion. Modern Ariidae catfish species occur in tropical and subtropical areas in coastal waters, estuarine regions, rivers, and lakes of continents and islands. There are about 34 genera and 156 species (Froese \& Pauly, 2021), mostly in shallow marine nearshore environments. However, 16 species of Ariidae are exclusively distributed in the freshwater systems of India, Bangladesh, Myanmar, Somalia, Madagascar, the Philippines, Laos, Indonesia, New Guinea, and Australia; four in North and Central America (Mexico and Guatemala); and two in South America (Brazil, Ecuador, and Peru) (Marceniuk \& Menezes, 2007; Marceniuk et al., 2019).

Cantarius nolfi was widely distributed in the Miocene of tropical America and is known from the lower Miocene Cantaure and Castillo formations in Venezuela, the lower Miocene Castilletes Fm. in Colombia, the lower to middle Miocene Pirabas Fm. in Brazil, the middle Miocene Pebas Fm. in Colombia and Peru, and the late Miocene Gatun Fm. in Panama (Aguilera et al., 2013, 2014, 2020; Monsch, 1998).

Fossil fish assemblages of ariids from freshwater deposits in the Americas are rare and have mostly been described in open nomenclature (e.g., Carrillo-Briceño et al., 2021; Lundberg, 1975; Monsch, 1998).

\section{Cantarius ohei n. sp.}

Figure 2A-F

Holotype. PIMUZ A/I 5001, Pebas Fm., middle Miocene, Iquitos (layer VI), Peru.

Etymology. Named after Fumio Ohe (Seto City, Japan) in recognition of his contribution to the study of fossil fish otoliths and interest in ariid catfishes.

Diagnosis. The combination of extremely thick lapillus otolith, regularly subquadrangular outline, reduced antero-mesial projection, posterior obtuse angle at the 


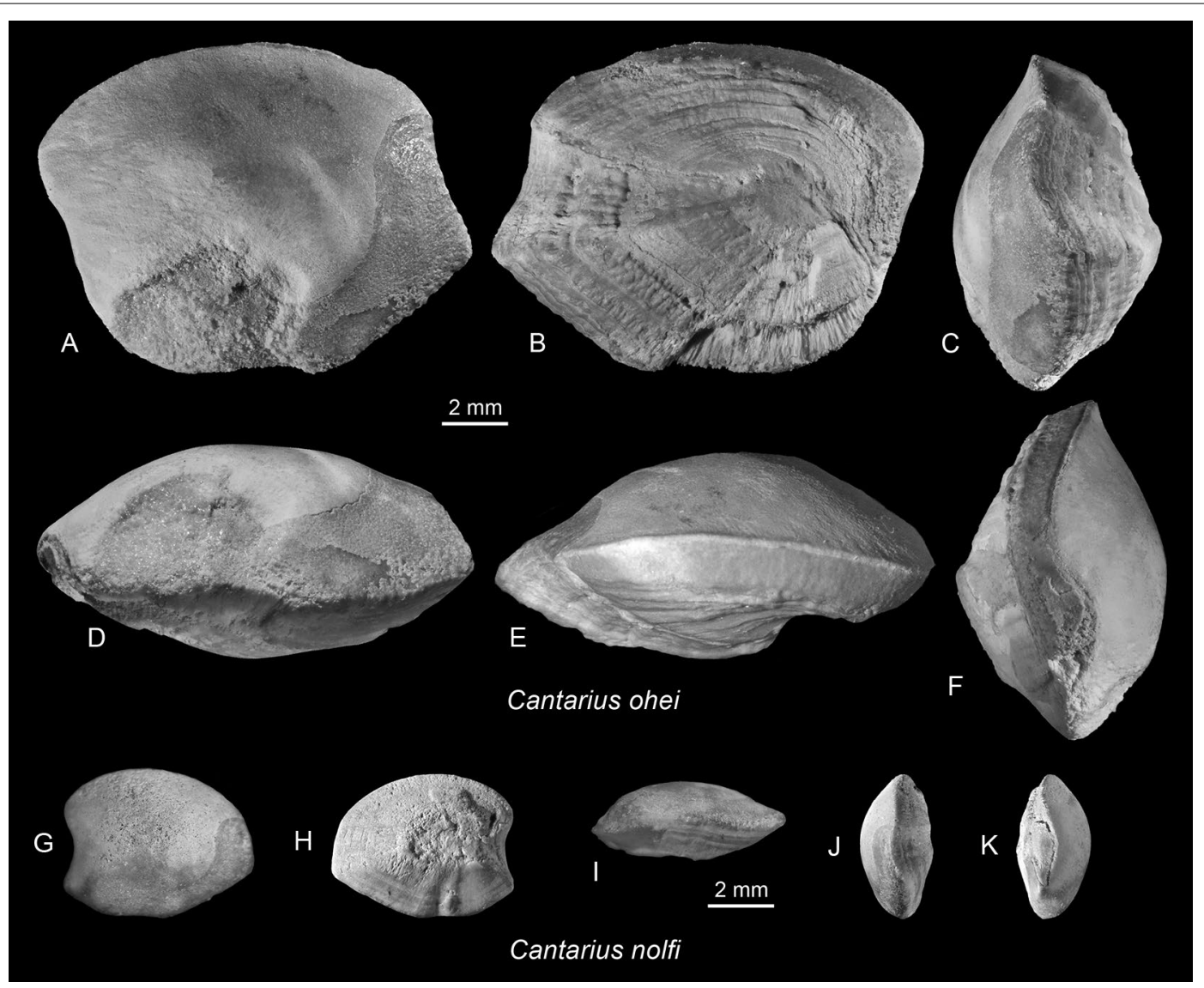

Fig. 2 A-F, Cantaurus ohei n. sp., PIMUZ A/I 5001 G-K, Cantaurus nolfi Aguilera et al., 2013, PIMUZ A/I 4998

posterior margin, and large mesial inward curvature distinguishes this species from other Ariidae species.

Description. The lapillus otolith is regularly oval to subquadrangular and extremely thick. Anterior margin slightly oblique and in antero-distal projection passes beyond antero-mesial projection. Caudal margin forming an obtuse angle at its tip. Antero-mesial projection reduced and forming a continuous arch with the most antero-distal margin of the otolith. Umbo located on anterior part of dorsal surface. Both dorsal and ventral surfaces strongly convex. Pseudocauda of mesial shallow depression forming an arch and expanding posteriorly. Mesial inward curvature forming a large and well-developed wedge oriented posteriorly. Ratio lapillus length to width: 1.3. Ratio lapillus length to thickness: 2.0.

Discussion. Both Cantarius species are associated with the same outcrop section in the Miocene Pebas Wetland System at the Telefunkenstation (telegraph station), $C$. nolfi in layers I and C. ohei $\mathrm{n}$. sp. in layer VI. We assume that these records represent only a first glimpse of the fossil freshwater ariid diversity that can be expected in the sedimentary basins of the western Amazon.

\section{Order Cichliformes \\ Family Cichlidae}

Genus Cichlasoma Swainson, 1839

\section{Cichlasoma bluntschlii n. sp.}

Figure 3A-D

Holotype. PIMUZ A/I 4996, Pebas Fm., middle Miocene, Iquitos (layer I), Peru.

Etymology. Named after Hans Bluntschli (1877-1962), who together with Bernhard Peyer, collected the otoliths described here in 1912.

Diagnosis. $\mathrm{OL}: \mathrm{OH}=1.15 ; \mathrm{OH}: \mathrm{OT}=2.8$. Outline nearly rhomboid with short rostrum, rounded posterior tip, middorsal and midventral angles. Ostium slightly upward directed at $15^{\circ}$; cauda with widened, flexed tip at $45^{\circ}$. $\mathrm{CaL}: \mathrm{OsL}=1.1 ; \mathrm{OsH}: \mathrm{CaH}=1.5$. Dorsal depression and ventral furrow distinct. 


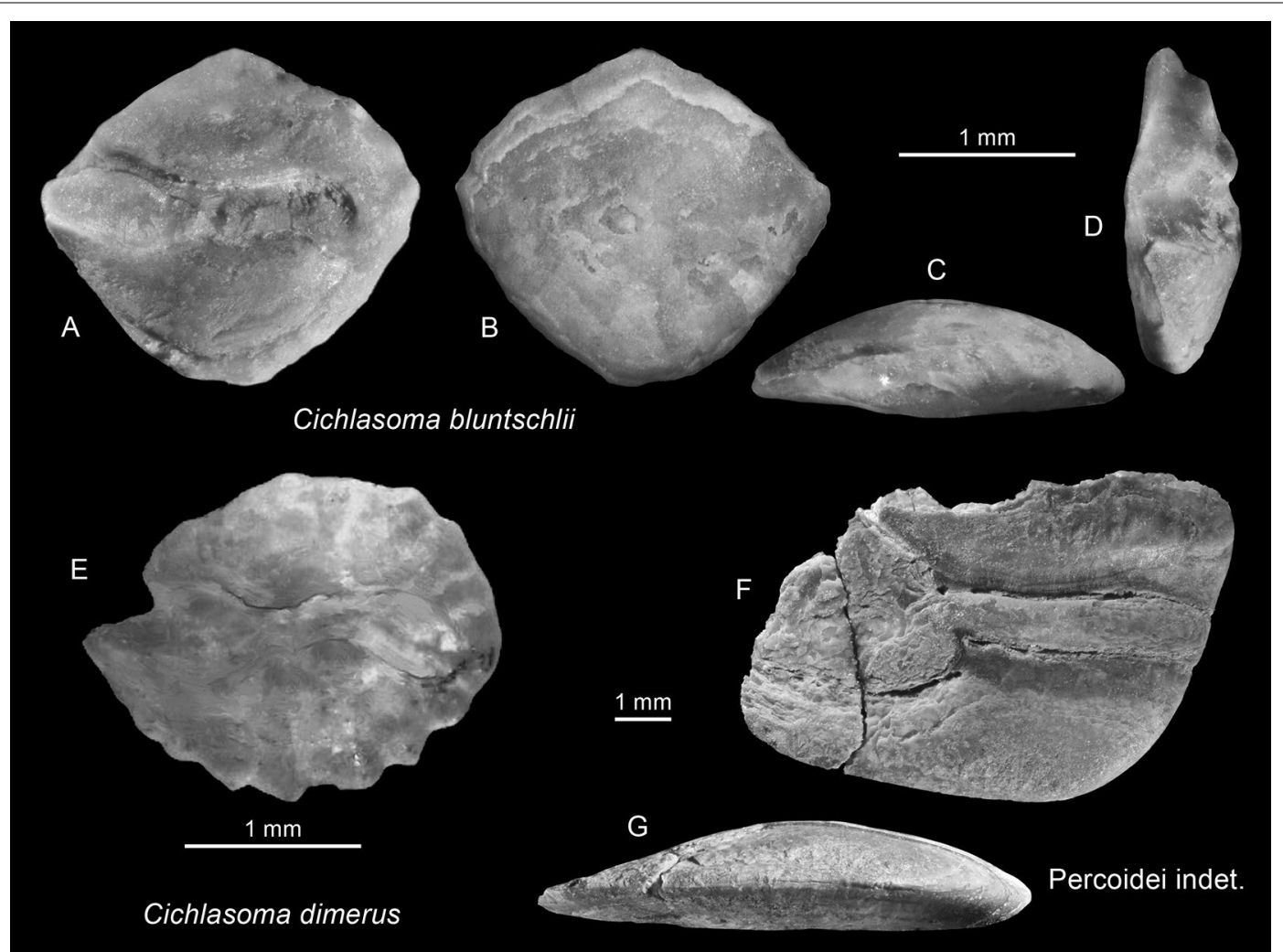

Fig. 3 A-D Cichlasoma bluntschlii n. sp., holotype, PIMUZ A/I 4996; E Cichlasoma dimerus (Heckel, 1840), freshwater from Argentina, refigured from Lombarte et al., 2006; F-G, Percoidei indet., PIMUZ A/I 4994

Description. A single, very well-preserved otolith of $2.2 \mathrm{~mm}$ in length, which is morphologically mature when compared to extant cichlid otoliths. Sulcus outline rhomboidal. Dorsal rim nearly straight and ascending from rostral tip to middorsal angle and slightly bent from middorsal angle to posterior tip; ventral rim slightly deeper than dorsal rim high, with rounded midventral angle. Rostrum moderately long, $15 \%$ of OL, with rounded tip; no excisura or antirostrum. Posterior tip slightly higher than rostrum, more distinctly rounded. All rims slightly and irregularly undulating.

Inner face strongly convex, with slightly supramedian and deepened sulcus. Ostium slightly bent upwards anteriorly, distinctly wider and slightly shorter than cauda, with well-defined ostial colliculum. Cauda narrower, slightly longer, very slightly upward oriented in its anterior two-thirds at about $5^{\circ}$, curved towards ventral at its posterior third at $45^{\circ}$, and slightly widened towards its rounded tip. Dorsal depression small but distinct, with marked crista superior towards sulcus. Ventral furrow very distinct, running moderately close to ventral rim of otolith. Outer face flat, nearly smooth, with few faint radial furrows on the ventral and dorsal fields.
Discussion. The family Cichlidae represents an important and large group in today's tropical South American freshwater regime, and, after characids and loricariids, the Neotropical cichlids, with at least 44 genera and more than 290 species, constitute the third speciose group of freshwater fishes in South America (see van der Sleen \& Albert, 2018). According to van der Sleen and Albert (2018), the genus Cichlasoma is represented by at least 12 species in the Amazon and Orinoco basins and coastal rivers of the Guianas and Trinidad. Otoliths are only known from a fraction of these, but it is highly unlikely that the Pebas Wetland System contained any fish species, which would be still present today. The cichlid otolith described here is regarded as typical due to the organization of the sulcus, which is characterized by the upward-oriented ostium and the broadened, downwardturned rounded caudal tip at an angle between $30^{\circ}$ and $50^{\circ}$. In addition, the distinct dorsal depression and ventral furrow add to the characterization. Of the known extant otoliths, those of Cichlasoma most closely resemble the shape and proportions of the otolith described here. For comparison, an otolith of the extant Cichlasoma dimerus (Heckel, 1840) is figured (Fig. 4E; reproduced from Lombarte et al., 2006). Note that the dorsal depression and the 


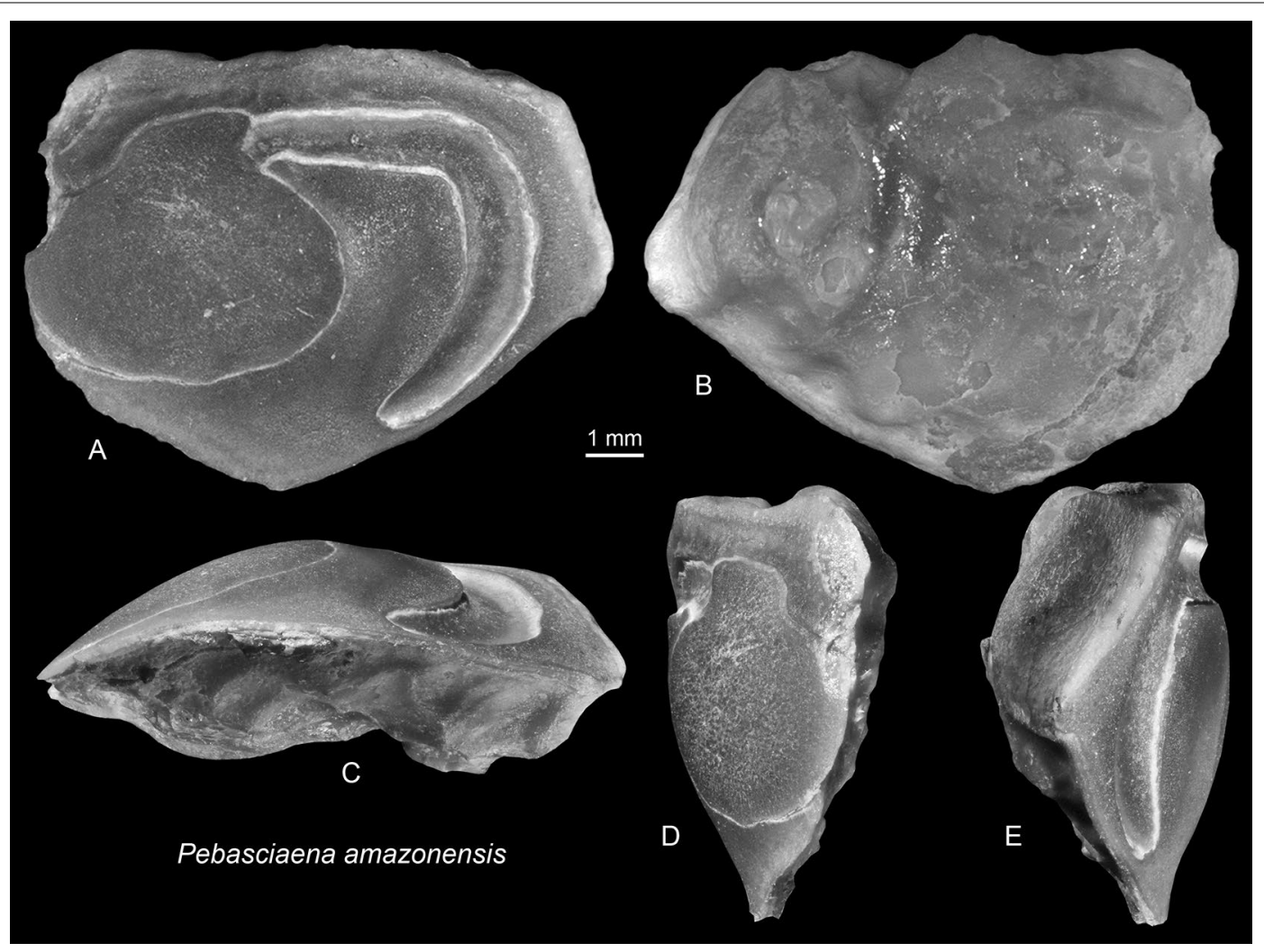

Fig. 4 A-E, Pebasciaena amazonensis n. gen. et n. sp., PIMUZ A/I 5006

ventral furrow are less clearly visible in the photograph of the extant specimen due to its semi-transparent nature. Cichlasoma bluntschlii differs from $C$. dimerus in the higher body and marked middorsal angle, as well as the absence of an excisura. Cichlasoma bluntschlii represents the first fossil otolith record in the world of the family (Nolf, 2013) and the first record of the genus as well.

\section{Order Perciformes \\ Suborder Percoidei Family indet}

\section{Percoidei indet.}

Figure 3F-G

Material. One specimen, PIMUZ A/I 4994, Pebas Fm., middle Miocene, Iquitos (layer I), Peru.

Discussion. A single large otolith of about $8.5 \mathrm{~mm}$ in length certainly represents some kind of perciform, probably percoid otolith that is too poorly preserved for any further identification. It is remarkable for a much widened ostium resembling those of sciaenid otoliths but differs in the completely straight cauda.

\section{Order Acanthuriformes}

\section{Suborder Sciaenoidei}

\section{Family Sciaenidae}

The morphometric measurements in the following descriptions of sciaenid otoliths follow that established in Aguilera et al. (2016).

\section{Genus Pebasciaena n. gen.}

Type species: Pebasciaena amazonensis n. sp.

Etymology. Combination of the formation name Pebas and the Pebas Wetland System with the type genus name Sciaena.

Diagnosis. An otolith-based genus of the family Sciaenidae with a typical sciaenid-type sulcus characterized by a wide and shallow ostium and a steeply curved, narrow, and somewhat deepened cauda. Morphometric key ratios: $\mathrm{OL}: \mathrm{OH}=1.35$, OsL:OsH=1.15; caudal curvature index $=0.7$; ostial-caudal interspace $=23 \%$ of SuL. Ostium with distinct postostial lobe and predorsal depression. Vertical section of cauda bent forward at its lower portion. Ventral rim with midventral angle. No distinct umbo on outer face.

Discussion. Pebasciaena shows a highly diagnostic otolith morphology that clearly differs from that of other freshwater sciaenid taxa. For example, it differs from otoliths of Plagioscion in the deep ventral rim, the lack 


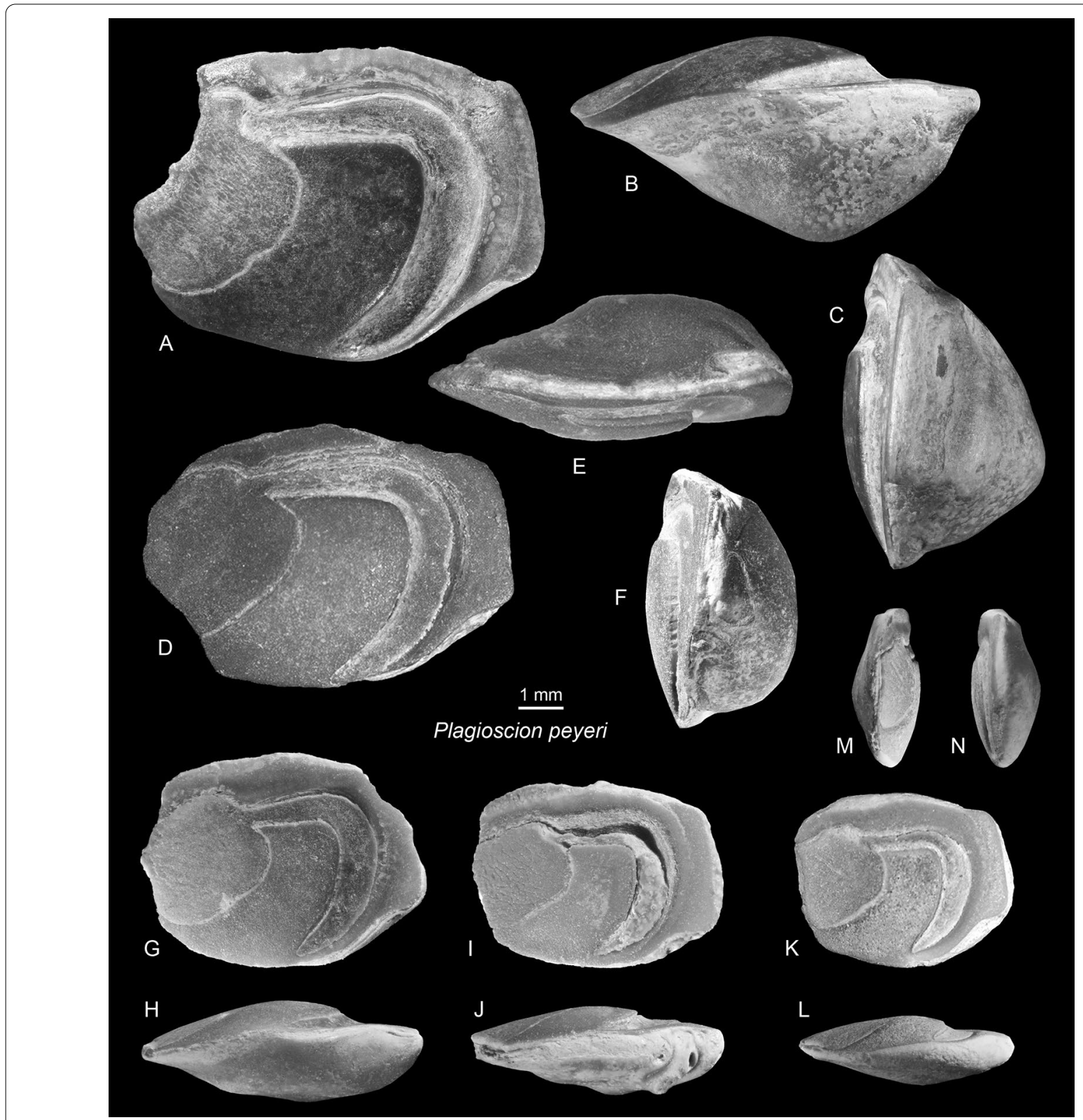

Fig. 5 A-N, Plagioscion peyeri n. sp., A-C, holotype, PIMUZ A/I 5062; D-F, paratype, PIMUZ A/I 5005; G-H, paratype, PIMUZ A/I 5003; I-J, paratype, PIMUZ A/I 4992; K-N, paratype, 4993

of an umbo on the outer face, and the shape of the very wide ostium with a strong postostial lobe and predorsal depression (vs. spatulate ostium shape). It shares with Pachypops and Pachyurus (see Schwarzhans, 1993 for figures) the lack of an umbo on the outer face, the more deeply curved ventral rim, and the general shape of the ostium but differs in the much larger and wider ostium and the narrower ostial-caudal interspace $(23 \%$ vs. $35-40 \%$ of SuL). The origin and relationships of the genus are unresolved. It could be related to Pachypops but also shows some resemblance to otoliths of certain marine sciaenids, such as Umbrina, Polycirrhus, and the extinct genus Frizzellithus. Pebasciaena differs from Umbrina and Polycirrhus otoliths in the cauda, which extends much below the limit of the ostium and the shape of the ventral rim. It differs from Frizzellithus in the less compressed shape $(\mathrm{OL}: \mathrm{OH}=1.35$ vs. $1.05-1.15)$, the less strongly widened ostium, and the slightly larger ostial-caudal interspace ( $23 \%$ vs. $17-22 \%$ of SuL). For 


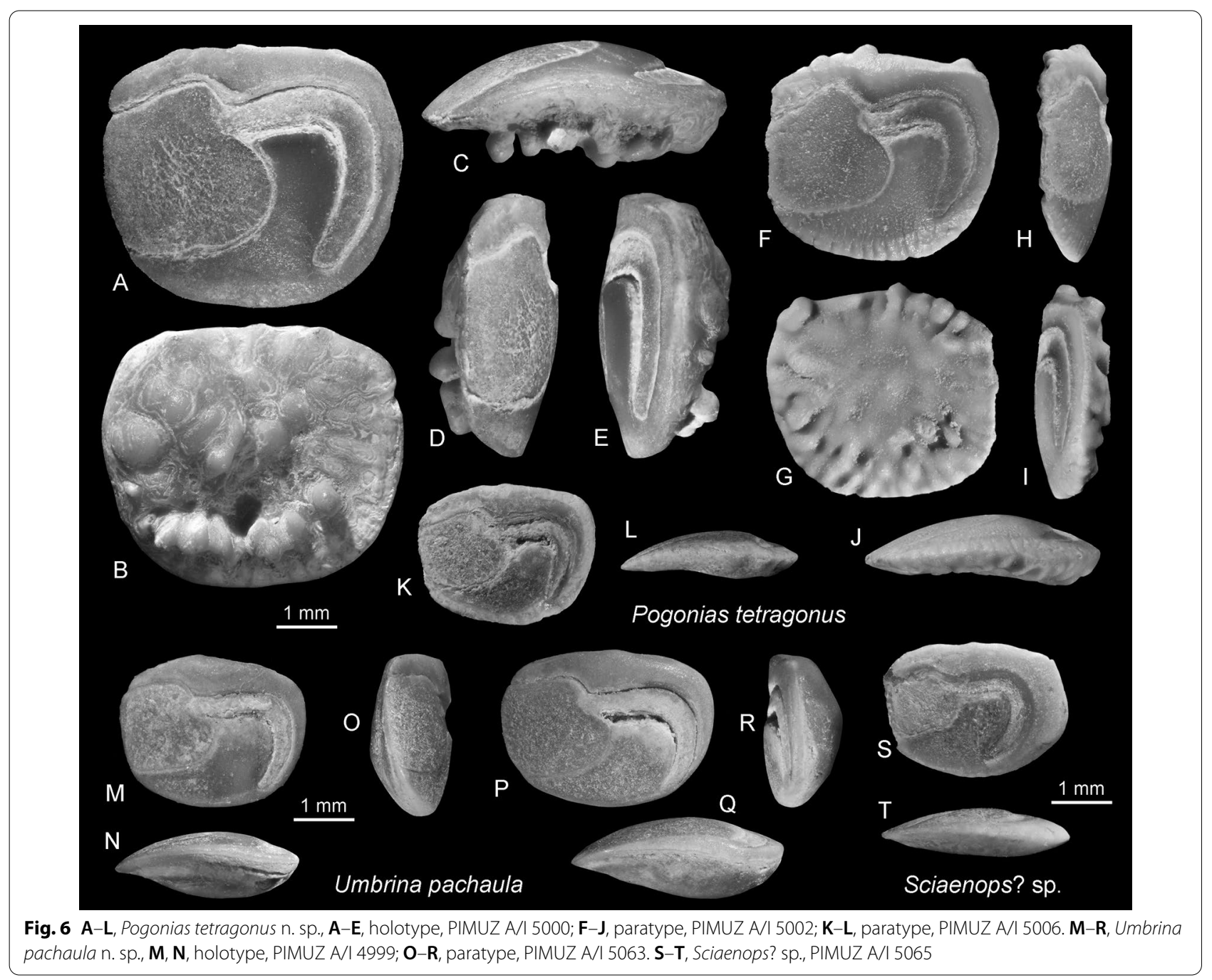

comparative extant and fossil otoliths of the mentioned genera, see Schwarzhans (1993) and Aguilera et al. (2016).

Species. Established as monospecific genus: Pebasciaena amazonensis $\mathrm{n}$. $\mathrm{sp}$.

\section{Pebasciaena amazonensis n. sp.}

Figure 4A-E

Holotype. PIMUZ A/I 5006, Pebas Fm., middle Miocene, Iquitos (layer VI), Peru.

Etymology. Named for its type location in the Amazon Basin.

Diagnosis. Same as genus (monospecific genus).

Description. A single, large, well-preserved specimen of $10.4 \mathrm{~mm}$ in length. $\mathrm{OH}: \mathrm{OT}=2.1$. Dorsal rim shallow, nearly flat, slightly undulating, with faint predorsal expansion. Ventral rim moderately deep, with distinct angle slightly in front of its middle, smooth. Anterior rim broadly rounded; posterior rim with obtuse angle at joint with dorsal rim and rounded angular tip at about level of central otolith axis.

Inner face distinctly convex, particularly in horizontal direction, with large, sciaenid-type sulcus extending over much of the space. Ostium very wide, shallow, convex, with distinct postostial lobe and predorsal depressions slightly bent downwards anteriorly. Cauda joining ostium near upper margin of latter and is long, narrow, somewhat deepened, steeply curving, extending beyond lower limit of ostium and bent forward in its lower third, with tapering tip. Dorsal and posterior fields very narrow, without distinct depressions; ventral field entirely smooth. Outer face thickset but without umbo; instead, somewhat depressed and coarsely and irregularly ornamented central region.

Discussion. See above to discussion of genus. Pebasciaena amazonensis is thought to represent an endemic freshwater genus and species that occurred in the Pebas Wetland System during the middle Miocene and has no 
direct derivatives in the contemporary freshwater (or marine) sciaenid assemblage of the Americas.

\section{Genus Plagioscion Gill, 1861}

\section{Plagioscion peyeri n. sp.}

Figure 5A-N

1998 Plagioscion sp.-Monsch: pl. 5, Fig. 23.

Holotype. Figure 5A-C, PIMUZ A/I 5062, Pebas Fm., middle Miocene, Iquitos (layer VI), Peru.

Paratypes. Five specimens: PIMUZ A/I 4992, 4993, layer I, PIMUZ A/I 5003, 5005, 5061, same data as holotype (layer VI).

Etymology. Named after Bernhard Peyer (1885-1963), who together with Hans Bluntschli, collected the otoliths described here in 1912.

Diagnosis. OL:OH=1.25-1.35. Ostium spatulate, distinctly inclined at $30-40^{\circ}$, relatively short. Downturned section of cauda gently curved, with its tapering tip pointing forward. Ostial-caudal interspace relatively wide, $30-35 \%$ of SuL. Umbo on outer face massive in large specimens, leading to $\mathrm{OH}$ :OT ratio of 1.5 .

Description. Moderately large, compact, and robust otoliths up to $9.3 \mathrm{~mm}$ in length (holotype). Otolith thick, with significant ontogenetic thickening from $\mathrm{OH}: \mathrm{OT}$ ratio of 2.5 at $5 \mathrm{~mm}$ length (Fig. $6 \mathrm{~K}-\mathrm{N}$ ) to 1.5 at $9.3 \mathrm{~mm}$ (Fig. 6A-C). Dorsal rim shallow, slightly curved; ventral deeper, regularly curved or deepest below tip of cauda (Fig. 6A), probably an ontogenetic effect. Anterior rim blunt, rounded, rather thin in lateral view and hence rarely completely preserved. Posterior rim blunt, with distinctly inframedian, short and obtuse angular tip. All rims smooth, with dorsal rim sometimes slightly undulating.

Inner face bent only in horizontal direction and nearly flat in vertical orientation. Sulcus large, occupying much space of inner face and leaving little room above and behind cauda. Ostium moderately large, about as wide as high, OsL:OsH $=0.9-0.95$, shallow, with small postostial lobe positioned high on posterior margin of ostium resulting in spatulate shape of distinctly downturned ostium. Cauda long, slightly deepened, distinctly and rather regularly curved with its tip pointing forward, caudal curvature index $=0.6-0.65$. Narrow and indistinct dorsal depression above horizontal part of cauda extending to variable degrees behind downturned part of cauda. Ventral field smooth. Outer face with broad, smooth umbo, which massively increases in size with ontogenetic growth (compare Fig. 6B, E, H, J, L).

Discussion. Plagioscion peyeri occurs more or less coeval to the marine Plagioscion marinus Aguilera \& de Aguilera (2003) known from the Cantaure Fm. of Venezuela, the Castilletes Fm. of the Guajira Peninsula in Colombia, and the Pirabas Fm. of Brazil. In fact, these two species are the most morphologically similar to the known fossil species of Plagioscion (see Aguilera et al., 2016 for figures). Plagioscion peyeri differs from $P$. marinus in being more compressed (OL:OH $=1.25-1.35$ vs. 1.4-1.5), the wider ostial-caudal interspace (30-35\% of SuL vs. $25-30 \%$ of $\mathrm{SuL}$ ), and the very thick development of the umbo on the outer face in specimens larger than $8 \mathrm{~mm}$ in length. It could well represent the freshwater vicariant species of $P$. marinus and would then be the oldest freshwater record for the now exclusively freshwater genus.

\section{Genus Pogonias Lacépède, 1802}

\section{Pogonias tetragonus n. sp.}

Figure 6A-L

Holotype. Figure 6A-E, PIMUZ A/I 5000, Pebas Fm., middle Miocene, Iquitos (layer VI), Peru.

Paratypes. Two specimens, PIMUZ A/I 5002, 5004, same data as holotype.

Further material. One poorly preserved, tentatively assigned specimen PIMUZ A/I 5066, same data as holotype, layer I.

Etymology. From tetragonos $($ Greek $)=$ quadratic, referring to the nearly perfectly quadratic outline of the otolith.

Diagnosis. $\mathrm{OL}: \mathrm{OH}=1.12-1.22$. Ostium wide, slightly inclined at $10-15^{\circ}$, with small postostial lobe, OsL:OsH $=0.95-1.05$. Cauda slightly upward oriented before gently curving downwards, not reaching deeper than ostium, caudal curvature index 0.6. Ostial-caudal interspace $25-27 \%$ of SuL. Outer face flat, ornamented with irregular tubercles.

Description. Moderately large otoliths with nearly perfectly quadratic shape up to $5 \mathrm{~mm}$ in length (holotype); $\mathrm{OH}: \mathrm{OT}=2.2-3.3$, depending on intensity of tubercles on outer face. Dorsal rim shallow, horizontal; ventral rim also nearly horizontal, slightly shorter than dorsal rim. Anterior and posterior rims nearly vertical slightly bent and slightly dorsally pronounced. All rims smooth or irregularly undulating, particularly dorsal rim.

Inner face distinctly convex in horizontal and vertical directions, with large sulcus occupying most of inner face. Ostium shallow, wide, large, nearly quadratic like outline of otolith, slightly inclined downwards. Cauda narrow, slightly deepened, with short, slightly upwardoriented anterior stretch and regularly curved, much longer downward-oriented section and running very close to posterior rim of otolith. Very narrow and indistinct dorsal depression above crista superior, which extends from rear part of ostium across horizontal part of cauda. Area behind cauda very narrow, smooth. Ventral field smooth. Outer face concave to flat, with several 
protruding tubercles ventrally in the largest specimen (Fig. 6C-E), resulting in a secondary thickening of the otolith. Outer face with numerous tubercles becomes increasingly prominent with size.

Discussion. Pogonias tetragonus is readily recognized by its nearly quadratic outline, which is also the main difference from the two extant species of the genus. Other differences are the lack of an expansion of the corner between dorsal and posterior rims and the relatively wide and slightly inclined ostium. The two extant species of Pogonias (P. cromis Linnaeus, 1766 and P. courbina [Lacépède, 1803]) have an antitropical distribution in the western Atlantic and are principally marine but may enter into brackish but not freshwater (Froese \& Pauly, 2021). However, the related monospecific genus Aplodinotus is today found exclusively in the freshwater systems of southeastern North America (Schwarzhans, 1993). Pogonias tetragonus resembles the extant Aplodinotus grunniens Rafinesque, 1819 in the outline of the otolith but has a distinctly larger ostium and narrower ostialcaudal interspace (25-27\% vs. 37\% of SuL). Furthermore, the fossil otolith-based genus Frizzellithus shows some similarity and could also be related. Pogonias tetragonus differs from the more or less coeval marine Frizzellithus longecaudatus (Nolf \& Aguilera, 1998) from Colombia and Venezuela in the nearly flat ventral rim (vs. deeply curved), the cauda not extending beyond the ventral margin of the ostium, the narrower ostium, and the wider ostial-caudal interspace (25-27\% vs. $17-22 \%$ of SuL). It thus appears that $P$. tetragonus is indeed best placed in the genus Pogonias, but it may not be directly related to the extant species. Instead, it might represent an extinct freshwater clade of the Pogonias group similar to Aplodinotus grunniens of North America.

\section{Genus Sciaenops Gill, 1863 \\ Sciaenops? sp.}

Figure 6S-T

Material. 1 specimen, PIMUZ A/I 5065, Pebas Fm., middle Miocene, Iquitos (layer I), Peru.

Discussion. A single, relatively small otolith of $3 \mathrm{~mm}$ in length could possibly represent a juvenile specimen of Sciaenops, but, in light of the habitat of the extant $S$. ocellatus in coastal marine environments of the tropical and subtropical western Atlantic, we assign the specimen only tentatively. The relatively small ostium, thin appearance, and wide ostial-caudal interspace resemble $S$. ocellatus otoliths but differs in the tip of the cauda being bent slightly forward (vs. vertical, not bent forward).

\section{Genus Umbrina Cuvier, 1816}

\section{Umbrina pachaula n. sp.}

Figure 6M-R

?1998 Umbrina sp.-Monsch: pl. 5, Fig. 24.

2016 Umbrina sp.-Aguilera, Schwarzhans \& Béarez: pl. 5, Fig. 12-13.

Holotype. Figure 6M-N, PIMUZ A/I 4999, Pebas Fm., middle Miocene, Iquitos (layer I), Peru.

Paratypes. One specimen, PIMUZ A/I 5063, same data as holotype.

Additional material. One poorly preserved specimen, PIMUZ A/I 4995, same data as holotype.

Etymology. From pachaulos (Greek)=thick, bulky, referring to the broadly thickened outer face of the otolith.

Diagnosis (based solely on specimens from the Pebas Fm.). $\mathrm{OL}: \mathrm{OH}=1.2-1.35 ; \quad \mathrm{OH}: \mathrm{OT}=1.95-2.3$. Ostium moderately wide, not inclined, with small postostial lobe, OsL:OsH $=1.05-1.1$. Cauda regularly curved, reaching slightly beyond ventral margin of ostium, caudal curvature index $0.8-0.9$. Ostial-caudal interspace $32-35 \%$ of SuL. Outer face broadly convex without distinct umbo, smooth.

Description. A relatively small, thick, massive otolith reaching about $5.5 \mathrm{~mm}$ in length (from Castilletes Fm.; holotype $3.1 \mathrm{~mm}$ ). Dorsal rim shallow, nearly horizontal, with faint middorsal angle; ventral rim regularly curving but also relatively shallow. Anterior and posterior rims broadly rounded, nearly vertical, slightly dorsally pronounced. All rims smooth.

Inner face distinctly bent along horizontal axis and much less in vertical direction. Ostium moderately wide and about as wide as long. Cauda narrow, regularly bent, slightly curving towards the tip, running very close to posterior rim of otolith, and reaching very close to posterior ventral rim. Dorsal field very narrow, without marked dorsal depression. Ventral field smooth. Outer face smooth, distinctly convex, with almost the entire area thereof being occupied by broad umbo; only anterior tip of otolith somewhat thinning.

Discussion. Umbrina is a species-rich genus with many extant and fossil (otolith-based) species, particularly in the Americas (Froese \& Pauly, 2021). The genus contains species with a flat outer face or marked postcentral umbo, but no species is known with an almost continuously and equally thickened outer face as is the case in $U$. pachaula. Other characters and proportions of otolith and sulcus in combination serve to differentiate $U$. pachaula from most other species, for instance the unusually wide 
ostial-caudal interspace, but are less conspicuous. Aguilera et al. (2016) reported few otoliths from the slightly older Castilletes Fm. of Colombia as Umbrina sp., which resemble $U$. pachaula very much in all aspects including the characteristic thickening of the outer face; as a result, we now place them in the same species. Small differences in the curvature of the tip of the cauda are considered to represent intraspecific variability. Today, Umbrina spp. are strictly marine, and no species is known to occur in freshwater. Hence, $U$. pachaula would thus represent the only species that occurred in both marine-estuarine and freshwater environments in the late early to middle Miocene. Its occurrence in the Castilletes Fm. is indeed near the mouth of the Pebas Wetland System to the Atlantic. We interpret $U$. pachaula as a marine species that was able to migrate upstream into freshwater environments.

Remarks: Three otoliths in Bluntschli and Peyer's collection are too poorly preserved to allow identification (PIMUZ A/I 4997, 5007, and 5064) (Table 2).

\section{Faunal evaluation}

The Pebas Wetland System is well known for, among its other characteristics, its rich endemic vertebrate fauna, some species of which were characterized by gigantism (e.g., Negri et al., 2010; Riff et al., 2010; both in Hoorn \& Wesselingh, 2010). In addition, a rich fish fauna, composed of shark and ray teeth and bony fishes represented primarily by isolated skeletal remains, has been accumulated (Lundberg et al. 2010 in Hoorn \& Wesselingh, 2010; Carrillo-Briceño et al., 2021). The skeletal remains of the bony fishes contain Osteoglossiformes (Arapaimidae), Characiformes (Anostomidae, Serrasalmidae, Cynodontidae, Erythrinidae, Parodontidae), Siluriformes (Callichthyidae, Loricariidae, Doradidae, Pimelodidae, Pseudopimelodidae, Ariidae), and Percomorpha (Cichlidae, rare Sciaenidae), all of which are typical and common freshwater fish families of the Amazon River system today. The otoliths recovered by Monsch (1998) and those described here differ in their composition in that Sciaenidae and Ariidae represent the dominant groups, and in addition, the otoliths discussed here include one representative each of the families Cichlidae (Cichlasoma bluntschlii) and an undescribed species of Thalassophryne (Batrachoididae) based on figures in Monsch (1998; as Dactyloscopidae indet.). The few recovered otoliths complement the data recovered from skeletal material. Bluntschli and Peyer collected the otoliths described here from two levels, one of which was also rich in skeletal fish remains and teeth, while the other bore exclusively otoliths (Table 1). The level with associated skeletal material and fish teeth indicate a freshwater environment characterized by common characiforms, cichliforms, and non-ariid siluriforms, as well as many pharyngeal sciaenid teeth.

With the exception of the single cichlid otolith, all of the otoliths belong to primarily marine fish families, which, however, are also distributed in South American freshwater systems today as either occasional migrants or with taxa that have adapted to freshwater from an original marine stock. Therefore, and in light of the fact that sporadic marine ingressions into the Pebas Wetland System have been suggested in the literature (e.g., Alvim et al., 2021; Monsch, 1998), these otoliths require a more detailed discussion, which follows below.

- Ariidae: The Ariidae are represented by two otolithbased species: Cantarius nolfi, which was originally described from coeval marine strata (Aguilera et al., 2013), and a second, Cantarius ohei n. sp., described here from the same outcrop of the Pebas Fm. The catfishes of the family Ariidae are primarily marine and brackish water fishes; however, many of them also occur in estuaries, and some migrate upstream in rivers. Chemical analyses of otolith and tissues of modern species support extensive movement of ariids throughout freshwater, estuarine, and marine habits (Avigliano et al., 2017; Condini et al., 2019; Pusey et al., 2020). In North, Central, and South America, five extant ariids species are found, primarily in fresh water (Betancur-R \& Willink, 2007; Hubbs \& Miller, 1960; Marceniuk \& Menezes, 2007; Marceniuk et al., 2019). However, 16 extant species of Ariidae are exclusively found in the freshwater of Africa, Asia, India, and Australia (Kailola \& Pierce, 1988; Kailola, 1990, 2000; Ng, 2003; Pusey et al., 2017). Cantarius nolfi may be considered an euryhaline fish that inhabited coastal marine ecosystems during the early Miocene and may have been able to migrate into freshwater systems. Cantarius ohei, in contrast, could represent a freshwater ariid in the Pebas Wetland System, since it is missing from coeval marine environments but cannot be used as an ecological indicator until further research has been conducted.

- Sciaenidae: This is the largest and most diverse family represented by otoliths from the Pebas Fm. Sciaenids are typical shallow-water marine fishes, often occurring in the vicinity of deltas and freshwater discharge into the sea, and many species are known to migrate upstream into freshwater (Trewavas, 1977). In South America, the extant sciaenids species of the genera Pachypops, Pachyurus, Plagioscion and Petilipinnis occur exclusively in freshwater (Casatti, 2003), and one genus is found in the freshwater of North America (Aplodinotus). In the Pebas Wetland System, 
we identified species of the genera Plagioscion, Pogonias, Umbrina, and the extinct Pebasciaena, which is exclusively known from here. In addition, there is a single potential juvenile otolith of Sciaenops, and Monsch (1998) mentioned a specimen of Xenotolithus sasakii Schwarzhans, 1993 (as "Genus Sciaenidarum" sasakii) but without figure. Monsch further recorded otoliths of Ctenosciaena cf. peruviana Chirichigno, 1974 (without figure), Ctenosciaena sp., Larimus sp., and Pachypops fourcroi (Lacépède, 1802) (without figure). The mentions of Ctenosciaena sp. and Larimus sp., which have been figured, reflect badly eroded juvenile specimens that cannot be allocated even to a genus; hence, the records of these two genera cannot be considered valid. For those we accept as confirmed, the ecological conditions in which they may have occurred must be considered ambiguous.

- Plagioscion is a strictly extant freshwater genus with seven valid extant species (Casatti, 2003). However, in the fossil record, four marine species are known from the early Miocene to the late Pliocene based on otoliths. The marine origin of the genus and its migration into freshwater are supported by the fossil records (Aguilera et al., 2016), and phylogenetic research (Cooke et al., 2011), and its occurrence in freshwater thus reflects a secondary development. Plagioscion peyeri now represents a fifth fossil otolith-based species, and the first that could be viewed as exclusively freshwater.

- Pebasciaena is a new extinct otolith-based genus exclusively known from the Pebas Wetland System. Its interrelationships remain elusive (see above), and it appears to represent an extinct endemic freshwater taxon.

- Pogonias is known from two extant species with an antitropical distribution in the Western Atlantic ( $P$. cromis from the northwestern Atlantic and P. courbina from the southwestern Atlantic), which are principally marine but may enter into brackish but not freshwater. However, the related monospecific genus Aplodinotus is today exclusively found in freshwater in southeastern North America (Schwarzhans, 1993). We consider Pogonias tetragonus to possibly represent an extinct freshwater clade of the group in the Pebas Wetland System similar to Aplodinotus grunniens of North America.

- Umbrina today is a species-rich and widely distributed genus that occurs primarily in marine environments, with only very few species migrating into the brackish environment of estuaries, mostly as juveniles, but not freshwater. Umbrina pachaula is also known from equivalent marine environments of Venezuela and would therefore represent a fish iden- tified with otoliths pointing to marine connectivity. However, it can also not be excluded that Umbrina species existed in the past that were more euryhaline in their mode of life and could have migrated from the sea into the Pebas Wetland System, like it is also postulated for Cantaurus nolfi (see above).

- Other sciaenids cannot be verified at this stage. Sciaenops and Xenotolithus, if verified, would both represent primarily marine groups; Ctenoscianea and Larimus are probably erroneous records. Pachypops would be a typical freshwater fish.

- Cichlidae: The single occurrence of a cichlid otolith (Cichlasoma bluntschlii) represents the only record of an unambiguous freshwater fish in the otolith assemblage. Furthermore, it is associated with a multitude of skeletal cichlid remains in the Pebas Fm. The occurrence of an unidentifiable large percoid otolith indicates the presence of further taxa that may not be reflected in the skeletal material.

- Batrachoididae: Monsch (1998) figured a small otolith as representing the family Dactyloscopidae, a stenohaline marine fish family, which, based on his photograph, we would interpret as representing a species of the batrachoid genus Thalassophryne. Thalassophryne is the only batrachoid genus, which includes an extant freshwater species exclusively found in the Amazon River scheme.

\section{Conclusions and outlook}

The collection of otoliths gathered by Bluntschli and Peyer in 1912, while relatively small, nevertheless contains an important addition to the fossil bony fish association so far known from the Pebas Fm. The otolith association is dominated by a variety of sciaenids, accompanied by a few ariids, cichlids, and possibly a batrachoidid, most of which are underrepresented by skeletal finds (except for the Cichlidae). The skeletal finds mostly stem from stenohaline freshwater fishes, many of which are from the Ostariophysi. Their delicate sagittae have never been found in the fossil record. Their lapilli are larger than the sagittae but may still be relatively small and thus rarely recognized and sampled in the fossil record, except for the very large ariid lapilli. In contrast, sciaenid otoliths are large and morphologically diverse and are more readily sampled. Therefore, some of the observed discrepancies between skeletal and otolith findings could be due to bias from sampling attitudes. Nevertheless, the otoliths add another interesting piece to the puzzle of the extinct fauna of the Pebas Wetland System. This piece indicates that potentially some exchange occurred between marginal marine environments and the Pebas Wetland System and that freshwater adaptations 
possibly existed in the Pebas Wetland System, which later became extinct. We believe that the Pebas Fm. may offer many more prospects for otolith recovery and that such data could further contribute to better understanding this unique vanished biotope. We hope that this study will encourage future researchers to search for more otoliths when sampling locations in the Pebas Fm. for fossils.

\begin{abstract}
Acknowledgements
We thank M. Sanchez-Villagra, Aldo Benitez Palomino and Christian Klug (Zürich) for their support to our research. Special thanks also to Frank Wesselingh (Leiden) and Rodolfo salas Gismondi (Lima) We thank Gary Stringer (West Monroe, Louisiana) and an anonymous reviewer for their constructive comments und suggestions, and the editor Daniel Marty for the seamless manuscript management.
\end{abstract}

\section{Authors' contributions}

WS, OA, JDC-B and TMS conceived the study. The following authors performed the taxonomic work: WS, OA and JDC-B. WS and JDC-B: processed, prepared fossils and took photographs. WS and JDC-B prepared figures and/or tables. WS, OA, JDC-B wrote partial drafts of the manuscript. WS, OA, JDC-B and TMS prepared the final draft, which was approved by all authors. All authors read and approved the final manuscript.

\section{Funding}

This work was supported by a Georges und Antoine Claraz-Donation Grant (2019) granted to Torsten Scheyer and Jorge Carrillo-Briceño. A mobility Grant (2018) Centro Latinoamericano-Suizo University of San Gallen and the Leading House for the Latin American Region, and Graduate Campus Grants (2019) of the University of Zurich grants, to Jorge Carrillo-Briceño, and Torsten Scheyer also acknowledges funding by the SNF (31003A-179401). The Brazilian Council of Science and Technological Development-CNPq (Grant 404937/2018-7 and productivity fellowships 305269/2017-8), and the Fundação Carlos Chagas Filho de Amparo à Pesquisa do Estado do Rio de Janeiro-FAPERJ (Grant E-26/201.035/2021 to OA) supported Orangel Aguilera.

\section{Availability of data and materials}

All the fossil specimens described here are freely available for study at the Palaeontological Institute and Museum of the University of Zurich, Switzerland. All data generated or analyzed during this study are included in this published article.

\section{Declarations}

\section{Competing interests}

The authors declare that they have no conflict of interest.

\section{Author details}

'Zoological Museum, Natural History Museum of Denmark, Universitetsparken 15, 2100 København, Denmark. ${ }^{2}$ Ahrensburger Weg 103, 22359 Hamburg, Germany. ${ }^{3}$ Marine Biology Department, Paleoecology and Global Changes Laboratory, Fluminense Federal University (UFF), Campus Gragoatá, Bloco M, Lab. 110, Niterói, Rio de Janeiro CEP. 24210-201, Brazil. " Universität Zürich, Paläontologisches Institut Und Museum, Karl-Schmid-Straße 4, 8006 Zürich, Switzerland.

Received: 1 December 2021 Accepted: 18 January 2022 Published online: 24 February 2022

\section{References}

Aguilera, O., \& De Aguilera, D. R. (2003). Two new otolith-based sciaenid species of the genus Plagioscion from South American Neogene marine sediments. Journal of Paleontology, 77(6), 1133-1138.

Aguilera, O. A., Moraes-Santos, H., Costa, S., Ohe, F., Jaramillo, C., \& Nogueira, A. (2013). Ariid sea catfishes from the coeval Pirabas (Northeastern Brazil), Cantaure, Castillo (Northwestern Venezuela), and Castilletes (North
Colombia) formations (early Miocene), with description of three new species. Swiss Journal of Palaeontology, 132, 45-68.

Aguilera, O. A., Schwarzhans, W., Moraes-Santos, H., \& Nepomuceno, A. (2014). Before the flood: Miocene otoliths from eastern Amazon Pirabas Formation reveal a Caribbean-type fish fauna. Journal of South American Earth Sciences, 56, 422-446. https://doi.org/10.1016/j.jsames.2014.09.021

Aguilera, O. A., Schwarzhans, W., \& Béarez, P. (2016). Otoliths of the Sciaenidae from the Neogene of tropical America. Palaeo Ichthyologica, 14, 7-90.

Aguilera, O. A., Lopes, R. T., Rodriguez, F., dos Santos, T. M., Rodrigues-Almeida, C., Almeida, P., Machado, A. S., \& Moretti, T. (2020). Fossil sea catfish (Siluriformes; Ariidae) otoliths and in-skull otoliths from the Neogene of the Western Central Atlantic. Journal of South American Earth Sciences, 101 102619. https://doi.org/10.1016/j.jsames.2020.102619

Alvim, A. M. V., Santos, R. V., Roddaz, M., Antoine, P.-O., Ramos, M. I. F., \& do Carmo, D.A. (2021). Fossil isotopic constraints (C, O and 875r/86Sr) on Miocene shallow-marine incursions in Amazonia. Palaeogeography, Palaeoclimatology, Palaeoecology, 573, 110422.

Antoine, P.-O., Baby, P., Benammi, M., Brusset, S., De Franceschi, D., \& Espurt, N., et al. (2007). The Laventan Fitzcarrald local fauna, Amazonian Peru. In: 4th European Meeting on Paleontology and Stratigraphy of Latin America, 8 Cuadernos del Museo Geominero, Madrid p 19-24.

Antoine, P.-O., Abello, M. A., Adnet, S., Altamirano Sierra, A. J., Baby, P., et al. (2016). A 60-million-year Cenozoic history of western Amazonian ecosystems in Contamana, eastern Peru. Gondwana Research, 31, 30-59.

Avigliano, E., Leisen, M., Romero, R., Carvalho, B., Velasco, G., Vianna, M., Barra, F., \& Volpedo, A. V. (2017). Fluvio-marine travelers from South America: Cyclic amphidromy and freshwater residency, typical behaviors in Genidens barbus inferred by otolith chemistry. Fisheries Research, 193, 184-194. https:// doi.org/10.1016/j.fishres.2017.04.011

Betancur-R, R., \&Willink, P.W. (2007). A new freshwater ariid (Otophysi: Siluriformes) from the Rio Usumacinta Basin. Copeia, 2007(94), 818-828.

Betancur-R, R., Broughton, R. E., Wiley, E. O., Carpenter, K., López, J. A., Li, C., et al. (2013). The tree of life and a new classification of bony fishes. PLoS Currents. https://currents.plos.org/treeoflife/index.html\%3Fp=4341.html

Bianucci, G., Lambert, O., Salas-Gismondi, R., Tejada, J., Pujos, F., Urbina, M., et al. (2013). A Miocene relative of the Ganges River dolphin (Odontoceti, Platanistidae) from the Amazonian Basin. Journal of Vertebrate Paleontology, 33(3), 741-745.

Boonstra, M., Ramos, M. I. F., Lammertsma, E. I., Antoine, P. O., \& Hoorn, C. (2015). Marine connections of Amazonia: Evidence from foraminifera and dinoflagellate cysts (early to middle Miocene, Colombia/Peru). Palaeogeography, Palaeoclimatology, Palaeoecology, 417, 176-194.

Carrillo-Briceño, J. D., Aguilera, O. A., Benites-Palomino, A., Hsiou, A. S., Birindelli, J. L. O., Adnet, S., Cadena, E.-A., \& Scheyer, T. M. (2021). A historical vertebrate collection from the neogene of the Peruvian Amazon. Swiss Journal of Palaeontology, 140, 26. https://doi.org/10.1186/s13358-021-00239-7

Casatti, L. (2003). Family Sciaenidae. In: Reis, R.E., Kullander, S.O. and Ferraris, C.J. (eds.) Check list of the freshwater fishes of South and Central Americal. Porto Alegre, Brazil, 599-602.

Chabain, J., Antoine, P.-O., Altamirano-Sierra, A. J., Marivaux, L., Pujos, F., Salas Gismondi, R., et al. (2017). Cenozoic batoids from Contamana (Peruvian Amazonia) with focus on freshwater potamotrygonins and their paleoenvironmental significance. Geobios, 50(5), 389-400.

Chirichigno, N.F. (1974). Clave para identificar los peces marinos del Peru. Callao: Instituto del mar del Peru, 44.

Condini, M. V., Pereyra, P. E. R., Garcia, A. M., Saint'pierre, T. D., Ceni, G., Lugo, R., Fontoura, N. F., Vieira, J. P. \& Albuquerque, C. Q. (2019). Use of fresh water by an estuarine-resident marine catfish: Evidence from gonadal and otolith chemistry analyses. Journal of the Marine Biological Association of the United Kingdon. https://doi.org/10.1017/S0025315419000493

Cooke, G. M., Chao, N. L., \& Beheregaray, L. B. (2011). Marine incursions, cryptic species and ecological diversification in Amazonia: The biogeographic history of the croaker genus Plagioscion (Sciaenidae). Journal of Biogeography. https://doi.org/10.1111/j.1365-2699.2011.02635.x

Cozzuol, M. A. (2006). The Acre vertebrate fauna: Age, diversity, and geography. Journal of South American Earth Sciences, 21(3), 185-203.

de Greve, L. (1938). Eine Molluskenfauna aus dem Neogen von Iquitos am Oberen Amazonas in Peru. Abhandlungen Der Schweizerischen Paläontologischen Gesellschaft, 61, 1-133.

Froese, R., \& Pauly, D. (2021). FishBase. World Wide Web electronic publication. Accessed October 2021. https://www.fishbase.se/search.php 
Gross, M., Piller, W. E., Ramos, M. I., da Silva, D., \& Paz, J. (2011). Late Miocene sedimentary environments in south-western Amazonia (Solimões Formation; Brazil). Journal of South American Earth Sciences, 32(2), 169-181.

Heckel, J. (1840). Johann Natterer's neue Flußfische Brasiliens. Abt. 1. Die Labridontidae. Annalen Des Wiener Museums Der Naturgeschichte, 2, 327-470.

Hoorn, C., \& Wesselingh, F. (2010). Amazonia, Landscape and Species Evolution: A Look into the Past. Blackwell Publishing.

Hoorn, C., Wesselingh, F. P., ter Steege, H., Bermudez, M. A., Mora, A., Sevink, $J$. , et al. (2010). Amazonia through time: Andean uplift, climate change, landscape evolution, and biodiversity. Science, 330(6006), 927-931.

Hubbs, C. L., \& Miller, R. R. (1960). Potamarius, a new genus of ariid catfishes from the fresh waters of Middle America. Copeia, 1960(2), 101-112.

Jaramillo, C., Romero, I., D’Apolito, C., Bayona, G., Duarte, E., Louwye, S., et al. (2017). Miocene flooding events of western Amazonia. Science Advances, 3(5), e1601693.

Joseph, S. A., Casapía, M., Blouin, B., Maheu-Giroux, M., Rahme, E., \& Gyorkos, T. W. (2014). Risk Factors Associated with Malnutrition in One-Year-Old Children Living in the Peruvian Amazon. PLOS Neglected Tropical Diseases, 8(12), e3369.

Kailola, P. J. (1990). A review of the freshwater fork-tailed catfushes (Pisces: Ariidae) of northern New Guinea with descriptions of two new species. Records of the Western Australian Museum Supplement, 4, 1-30.

Kailola, P. J. (2000). Six new species of fork-tailed catfishes (Pisces, Teleostei, Ariidae) from Australia and New Guinea. The Beagle: Records of the Museums and Art Galleries of the Northern Territory, 16, 127-214.

Kailola, P. J., \& Pierce, B. E. (1988). A new freshwater catfish (Pisces: Ariidae) from norther Australia. Records of the Western Australian Museum Supplement, 14, 73-89.

Linhares, A. P., de Gaia, V. d. C. S. \& Ramos, M. I. (2017). The significance of marine microfossils for paleoenvironmental reconstruction of the Solimões Formation (Miocene), western Amazonia, Brazil. Journal of South American Earth Sciences, 79, 57-66.

Lombarte, A., Chic, Ò., Parisi-Baradad, V., Olivella, R., Piera, J., \& García-Ladona, E. (2006). A web-based environment from shape analysis of fish otoliths. The AFORO Database. Scientia Marina, 70, 147-152.

Lundberg, J.G. (1975). 'The fossil catfishes of North America. In Claude W. Hibbard Memorial Volume 2. Papers on Paleontology 11, 51 pp.

Marceniuk, A., \& Menezes, N. (2007). Systematic of the family Ariidae (Ostariophysi, Siluriformes), with a redefinition of the genera. Zootaxa, 1416, $1-126$.

Marceniuk, A. P., Marchena, J., Oliveira, C., \& Betancur-R., R. (2019). Chichaysuyoa, a new genus of the fish family Ariidae (Siluriformes), with a redescription of Chinchaysuyoa labiate from Ecuador and a new species description from Peru. Zootaxa, 4551(3), 361-378. https://doi.org/10. 11646/zootaxa.4551.3.5

Monsch, K. A. (1998). Miocene fish faunas from the northwestern Amazonia basin (Colombia, Peru, Brazil) with evidence of marine incursions. Palaeogeography, Palaeoclimatology, Palaeoecology, 143(1), 31-50.

Negri, F. R., Bocquentin-Villanueva, J. C., Ferigolo, J., \& Antoine, P.-O. (2010). A Review of Tertiary mammal faunas and birds from western Amazonia. In C. Hoorn \& F. P. E. Wesselingh (Eds.), Amazonia: Landscape and Species Evolution: A Look into the Past (pp. 245-258). Oxford: Wiley-Blackwell.

Nelson, J. S., Grande, T. C., \& Wilson, M. V. H. (2016). Fishes of the World (5th ed.) Wiley.

$\mathrm{Ng}, \mathrm{H} . \mathrm{H}$. (2003). Arius verrocosus, a new species of freshwater ariid catfish (Teleostei: Ariidae) from the Mekong River. Occasional Papers of the Museum of Zoology the University of Michigan, 734, 1-14.

Nolf, D. (2013). The diversity of fish otoliths, past and present. Royal Belgian Institute of Natural Sciences.

Nolf, D., \& Aguilera, O. A. (1998). Fish otoliths from the Cantaure Formation (early Miocene of Venezuela). Bulletin De L'institut Royal Des Sciences Naturelles De Belgique, 68, 237-262.

Pujos, F., Albino, A. M., Baby, P., \& Guyot, J.-L. (2009). Presence of the extinct lizard Paradracaena (Teiidae) in the Middle Miocene of the Peruvian Amazon. Journal of Vertebrate Paleontology, 29(2), 594-598.

Pusey, B. J., Burrows, D. W., Kennard, M. J., Perna, C. N., Unmack, P. J., Allsp, Q., \& Hammer, M. P. (2017). Freshwater fishes of northern Australia. Zootaxa, 4253(1), 1-104. https://doi.org/10.11646/zootaxa.4253.1.1

Pusey, B. J., Jardine, T. D., Bunn, S. E., \& Douglas, M. M. (2020). Sea catfishes (Ariidae) feeding on freshwater floodplains of northern Australia. Marine and Freshwater Research. https://doi.org/10.1071/MF20012
Riff, D., Romano, R. P. S., Oliveira, G. R., \& Aguilera, O. A. (2010). Neogene Crocodile and Turtle Fauna in Northern South America. In C. Hoorn \& F. P. E. Wesselingh (Eds.), Amazonia: Landscape and Species Evolution: A Look into the Past (pp. 259-280). Oxford: Wiley-Blackwell.

Roddaz, M., Baby, P., Brusset, S., Hermoza, W., \& Maria Darrozes, J. (2005). Forebulge dynamics and environmental control in Western Amazonia: The case study of the Arch of Iquitos (Peru). Tectonophysics, 399(1), 87-108.

Salas-Gismondi, R., Baby, P., Antoine, P.-O., Pujos, F., Benammi, M., Espurt, N., et al. (2006). Late middle Miocene vertebrates from the Peruvian Amazonian basin (Inuya and Mapuya Rivers, Ucayali): Fitzcarrald Expedition 2005. XIII Congreso Peruano de Geología, 643-646.

Salas-Gismondi, R., Flynn, J. J., Baby, P., Tejada-Lara, J. V., Wesselingh, F. P., \& Antoine, P.-O. (2015). A Miocene hyperdiverse crocodylian community reveals peculiar trophic dynamics in proto-Amazonian mega-wetlands. Proceedings of the Royal Society b: Biological Sciences, 282(1804), 20142490.

Salas-Gismondi, R., Flynn, J. J., Baby, P., Tejada-Lara, J. V., Claude, J., \& Antoine, P.-O. (2016). A New 13 Million Year Old Gavialoid Crocodylian from ProtoAmazonian Mega-Wetlands Reveals Parallel Evolutionary Trends in Skull Shape Linked to Longirostry. PLoS ONE, 11(4), e0152453.

Schwarzhans, W. (1993). A comparative morphological treatise of recent and fossil otoliths of the family Sciaenidae (Perciformes). Piscium Catalogus, Otolithi Piscium, 1, 1-245.

Tejada-Lara, J. V., Salas-Gismondi, R., Pujos, F., Baby, P., Benammi, M., Brusset, S., et al. (2015). Life in proto-Amazonia: Middle Miocene mammals from the Fitzcarrald Arch (Peruvian Amazonia). Palaeontology, 58(2), 341-378.

Swainson, W. (1839). The natural history and classification of fishes, amphibians, \& reptiles, or monocardian animals (p. 448). Spottiswoode and Co.

Trewavas, E. (1977). The sciaenid fishes (croakers or drums) of the Indo-WestPacific. Transactions of the Zoological Society of London, 33, 253-541.

van der Sleen, P., \& Albert, J. S. (2018). Field Guide to the Fishes of the Amazon, Orinoco, and Guianas. New Jersey, Princenton University Press.

Wesselingh, F. P., Räsänen, M. E., Irion, G., Vonhof, H. B., Kaandorp, R., Renema, W., et al. (2002). Lake Pebas: A palaeoecological reconstruction of a Miocene, long-lived lake complex in western Amazonia. Cainozoic Research, $1(1-2), 35-81$

Wesselingh, F. P., Hoorn, M. C., Guerrero, J., Räsänen, M. E., Romero Pittmann, L., \& Salo, J. A. (2006). The stratigraphy and regional structure of Miocene deposits in western Amazonia (Peru, Colombia and Brazil), with implications for late Neogene landscape evolution. Scripta Geologica, 133, 291-322.

Wesselingh, F. P., Hoorn, C., Kroonenberg, S. B., Antonelli, A. A., Lundberg, J. G., Vonhof, H. B., et al. (2010). On the origin of Amazonian landscapes and biodiversity: A synthesis. In C. Hoorn \& F. P. Wesselingh (Eds.), Amazonia: Landscape and species evolution (pp. 421-432). Oxford.

\section{Publisher's Note}

Springer Nature remains neutral with regard to jurisdictional claims in published maps and institutional affiliations.

\section{Submit your manuscript to a SpringerOpen ${ }^{\circ}$ journal and benefit from:}

- Convenient online submission

- Rigorous peer review

- Open access: articles freely available online

- High visibility within the field

- Retaining the copyright to your article

Submit your next manuscript at springeropen.com 